\title{
PEMBENTUKAN PORTOFOLIO OPTIMAL PADA SAHAM PERBANKAN DALAM INDEKS LQ 45 DI MASA VAKSINASI COVID-19 MENGGUNAKAN MODEL INDEKS TUNGGAL
}

\author{
Galih Rhendra Putra $\circledast^{1)}$, Nabilla Aulia $\circledast^{2)}$ Rae Arun Sugara $\circledast^{3)}$ dan Wisudanto Mas Soeroto $\oplus^{4)}$ \\ 1,2,3,4 Manajemen Teknologi, Institut Teknologi Sepuluh Nopember Surabaya \\ 1,2,3,4 Jl. Cokroaminoto No.12A, Dr. Soetomo, Kec. Tegalsari, Kota Surabaya, Jawa Timur, 60264 \\ E-mail : galihputra.206032@mhs.its.ac.id ${ }^{1)}$, nabillaaulia.206032@mhs.its.ac.id ${ }^{2}$, sugara.206032@ mhs.its.ac.id ${ }^{3)}$, \\ wisudanto@feb.unair.ac.id ${ }^{4)}$
}

\begin{abstract}
ABSTRAK
Di masa Vaksinasi Covid-19, pertumbuhan ekonomi mulai meningkat kembali. Berbagai stimulus mulai dikurangi dikarenakan ekonomi masyarakat yang mulai membaik. Saat seperti ini merupakan waktu yang tepat bagi para investor untuk kembali menjajakan dananya pada instrumen investasi. Dengan melakukan investasi pada perbankan, investor tidak hanya mendapatkan Return, tetapi juga turut berkontribusi dalam meningkatkan kemampuan perbankan dalam memberikan kredit kepada masyarakat untuk kembali meningkatkan gairah ekonomi. Terdapat 7 emiten sektor perbankan yang tercatat dalam Indeks LQ45 periode Tahun 2016 - 2020. Dengan tetap mengutamakan prinsip diversifikasi, peneliti menggunakan Model Indeks Tunggal dalam perhitungan proporsi investasi untuk membentuk portofolio yang optimal di saham sektor perbankan dalam Indeks LQ45 periode Tahun 2016 - 2020. Penelitian ini bertujuan untuk menambahkan referensi lain terkait pembentukan portofolio optimal menggunakan model indeks tunggal khususnya untuk emiten - emiten yang bergerak di sektor perbankan. Dari hasil penelitian ini didapatkan hasil untuk memperoleh Return optimal perlu dibentuk portofolio optimal, salah satunya pada saham - saham sektor perbankan di dalam Indeks LQ45 menggunakan model indeks tunggal periode Tahun 2016 - 2020 menghasilkan 3 diversifikasi saham beserta dengan proporsi dana dari masing - masing saham yaitu: Bank Central Asia (BBCA) dengan proporsi 56\%, Bank Rakyat Indonesia (BBRI) dengan proporsi $7 \%$, dan Bank BTPN Syariah (BTPS) dengan proporsi 37\%. Oleh sebab itu, calon investor yang akan berinvestasi saham khususnya di sektor perbankan hendaknya terlebih dahulu melakukan diversifikasi pada beberapa saham perusahaan sebagaimana diatas untuk memaksimalkan Return dan mengurangi risiko.
\end{abstract}

Kata Kunci: Saham, Sektor Perbankan, Indeks Tunggal, Indeks Lq45, Diversifikasi Saham

\section{PENDAHULUAN}

Ada banyak cara dalam mengelola dana, salah satunya adalah dengan berinvestasi. Investasi adalah bentuk pengelolaan dana guna mendapatkan keuntungan di masa yang akan datang. Investor masa kini sudah semakin sadar bahwa berinvestasi pada saham lebih menguntungkan dibandingkan dengan tabungan dan juga deposito. Namun selain karena keuntungan yang akan diperoleh, investor juga harus memiliki pengetahuan dan menimbang risiko atau sebab ketidakpastian apabila akan melakukan investasi. Oleh karena itu, memperkaya pengetahuan berkenaan dengan risiko investasi menjadi hal utama yang harus dimiliki calon investor, hal tersebut sangat penting untuk mengetahui seberapa jauh kemungkinan adanya penyimpangan dari hasil yang diharapkan oleh calon investor dan untuk memperkirakan keuntungan ataupun batas kerugian yang akan dihadapi oleh calon investor dari investasi yang dilakukan (Pratama and Budiyanto, 2016).

Dalam berinvestasi, diversifikasi sangatlah penting. Sebagaimana perumpamaan "Jangan menaruh telur di keranjang yang sama" begitu populer di kalangan investor baik pemula maupun expert. Menurut
(Oktaviani and Wijayanto, 2016) mengungkapkan di versivikasi dengan model indeks tunggal lebih menguntungkan dilihat dari kinerja portofolio yang dibandingkan dengan kinerja Indeks Harga Saham Gabungan (IHSG). Oleh karenanya pengetahuan tentang proporsi investasi juga dibutuhkan dalam membentuk portofolio yang optimal. Menurut (Nalini, 2014) seorang investor yang rasional tentunya bertujuan untuk mencapai hasil investasi optimal dengan risiko minimal, sehingga membentuk portofolio optimal adalah tugas yang menantang bagi individu sebagai calon investor. Hal ini sejalan dengan penelitian dari (Pardosi and Wijayanto, 2013) yang menyatakan meskipun tidak ada perbedaan antara return dari portofolio optimal dengan portofolio tidak optimal namun tetap disarankan untuk membuat portofolio optimal sebagai manfaat dari diversifikasi saham.

Saat ini Indonesia sedang dalam tahap pemulihan ekonomi pasca dilaksanakannya vaksinasi, setelah pandemic covid 19 menyerang Negara ini. Tidak di pungkiri bahwa pandemi covid 19 membawa dampak yang cukup besar untuk perekonomian Indonesia, sebagaimana yang diungkapkan oleh (Hadiwardoyo, 
2020) bahwa pembatasan aktivitas menimbulkan kerugian ekonomi secara massal, dan salah satu cara untuk menutup krisis ini adalah dengan mendongkrak perekonomian Indonesia. Pemulihan ekonomi pasca vaksinasi ini dapat terlihat dari mulai bangkitnya perdagangan domestik, kinerja tersebut didukung oleh meningkatnya investasi dan menguat nya nilai IHSG. IHSG sudah mulai merangkak naik dibandingkan akhir tahun 2020 yang lalu, meskipun konsumsi masyarakat masih lambat karena masih adanya peraturan pembatasan sosial.

Pemulihan ekonomi suatu negara sangat bergantung pada salah satunya yaitu kontribusi nyata dari industri keuangan atau perbankan. Perbankan selalu menjadi tulang punggung perkembangan ekonomi suatu negara, karena mereka mengumpulkan dana masyarakat dan sebagai mediator. Fungsi industri keuangan yaitu menyediakan fasilitas dan infrastruktur transaksi pembayaran, mengumpulkan dana, menyediakan mekanisme dan sistem penyaluran dana antar ruang dan waktu, menerapkan manajemen risiko, menyediakan informasi harga, dan mengatasi masalah ketimpangan informasi (asymmetric information).

Saat ini saham perbankan menjadi saham - saham yang cukup diminati di pasar modal. Dalam indeks LQ45 pada periode Januari 2015 sampai Desember 2020, tercatat ada 7 emiten dari sektor perbankan. Indeks LQ45 adalah merupakan perhitungan komprehensif dari 45 saham yang diseleksi melalui beberapa kriteria pemilihan. Selain penilaian atas likuiditas saham, seleksi atas saham - saham tersebut juga mempertimbangkan kapitalisasi pasar. Indeks LQ45 berisi 45 saham yang disesuaikan setiap enam bulan sekali (setiap awal bulan Februari dan Agustus). Sebagai calon investor tentunya sangat baik jika memilih untuk berinvestasi ke saham saham yang masuk dalam daftar indeks LQ45, sebab saham - saham yang terdaftar di dalam LQ45 memiliki tingkat likuiditas dan nilai kapitalisasi pasar yang tinggi, serta menjadi patokan naik turunnya harga saham di Bursa Efek Indonesia. Sejalan dengan penelitian (Dahlan, Topowijono and Z.A, 2013) dimana dikatakan bahwa saham - saham yang masuk dalam indeks LQ45 memiliki kinerja yang baik dan kapitalisasi pasar yang tinggi.

Investasi pada sektor perbankan tentunya memberikan kontribusi pada kemampuan institusi tersebut dalam memberikan kredit. Dan kredit yang diberikan kepada debitur tentunya akan berdampak pada pertumbuhan ekonomi.

Ada 7 emiten dari sektor perbankan yang tercatat di dalam indeks LQ45 pada periode Januari 2015 Desember 2020. Tentunya sebagai investor membutuhkan perhitungan proporsi investasi untuk membentuk portofolio yang optimal. Terdapat dua alat analisis yang dapat digunakan dalam menentukan proporsi yang optimal, yaitu Model Markowitz dan Model Indeks Tunggal. Para calon maupun investor lebih banyak memilih menggunakan analisis Model Indeks
Tunggal karena lebih mudah dan membutuhkan sedikit perhitungan, dengan tetap memperhatikan kondisi pasar dari Return dan risiko yang diharapkan. Seperti penelitian yang dilakukan oleh (Firdaus, Iwan. Anah, Sri. Nadira, 2018) dan juga (Oktaviani and Wijayanto, 2016) yang menggunakan model indeks tunggal karena dinilai lebih mudah untuk mengetahui proporsi masing - masing saham yang dipilih serta tingkat return dan risiko dari portofolio yang dihasilkan.

Penelitian seperti ini sudah pernah dilakukan sebelumnya, Penelitian dari (Pratama and Budiyanto, 2016) menunjukkan Portofolio optimal adalah portofolio yang memiliki nilai Excess Return to Beta (ERB) yang lebih besar dari nilai $\mathrm{Ci}$, dimana nilai $\mathrm{Ci}$ merupakan titik pembatas (cut-off point $C^{*}$ ) yang memiliki nilai ERB terakhir yang lebih besar dari nilai $\mathrm{Ci}$. Hasil penelitian dari 6 saham perusahaan pertambangan batubara yang menjadi sampel menunjukkan bahwa diperoleh 2 saham yang optimal sehingga didapatkan 1 kombinasi portofolio, yaitu kombinasi saham PT Bayan Resources Tbk. dan saham PT Resource Alam Indonesia Tbk. Penelitian dari (Firdausy, 2015) menyimpulkan bahwa risiko investasi dapat diminimalkan dengan diverifikasi, sedangkan untuk memperoleh return investasi optimal perlu dibentuk portofolio optimal dengan salah satunya pada saham LQ45 dengan menggunakan model indeks tunggal pada periode Februari 2011 - Juli 2014. Penelitian tersebut menghasilkan 14 saham yang membentuk portofolio optimal, yaitu AALI (0,42\%), PGAS (1,98\%), GGRM (2,35\%), INDF $(3,41 \%)$, BBNI $(4,20 \%)$, CPIN $(4,56 \%)$, LPKR $(4,72 \%)$, BMRI $(6,16 \%)$, UNVR $(6,68 \%)$, BBCA $(7,78 \%)$, BBRI $(10,31 \%)$, JSMR $(10,41 \%)$, SMGR $(18,36 \%)$, dan INTP $(18,66 \%)$. Untuk itu calon maupun investor yang akan menginvestasikan dananya dalam portofolio saham hendaknya melakukan diversifikasi pada beberapa saham guna mengurangi potensi risiko. Selain itu, dari penelitian yang dilakukan (Rarastiti, Handayani and Sudjana, 2013) yang meneliti perusahaan dari sektor Food and Beverages menyimpulkan bahwa untuk meminimalisasikan risiko, maka calon investor dapat memilih portofolio dari sektor perusahaan Food and Beverages dengan mengambil sebanyak 9 perusahaan. Terdapat 4 perusahaan yang membentuk portofolio optimal yaitu PT. Mayora Indah, Tbk (MYOR), Bintang Indonesia, Tbk (MLBI), PT. Delta Jakarta, Tbk (DLTA), PT. Sekar Laut, Tbk (SKLT) dan PT. Multi. Penelitian dari (Kewal, 2013) menunjukkan membentuknya portofolio optimal dengan menggunakan metode model indeks tunggal pada periode bullish menghasilkan 4 saham optimal yaitu (ASRI), (IND), (BBNI), dan (BKSL). Kemudian penelitian dari (Darmawan and Purnawati, 2015) yang mengambil sampel dari LQ45 menunjukkan portofolio optimal yang terdiri dari (JSMR), (BBCA), dan (UNVR) memberikan tingkat keuntungan sebesar $2,67 \%$ dengan tingkat risiko $1,24 \%$. Kemudian penelitian dari (Wibowo, Rahayu and Endang, 2014) menunjukkan hasil yang lebih ekstrem lagi dengan tingkat keuntungan 
(return) portofolio mencapai 3,32\% dengan tingkat risiko hanya $0,22 \%$.

Berdasarkan penelitian - penelitian terdahulu, dengan membuat variasi yang berbeda menjadi fenomena yang menarik untuk kembali melakukan penelitian mengenai pembentukan portofolio yang optimal. Pada penelitian kali ini, peneliti akan mengangkat pembentukan portofolio optimal khususnya di sektor perbankan, karena sektor perbankan sangat mendominasi pembentukan Indeks Harga Saham Gabungan (IHSG), kinerja saham perbankan selalu menduduki 10 besar saham - saham paling diminati oleh investor. Berdasarkan latar belakang yang telah dijelaskan sebelumnya, tujuan yang ingin dicapai dari penelitian ini adalah untuk mengetahui saham - saham yang dapat membentuk portofolio optimal pada sektor saham perbankan yang terdaftar dalam Indeks LQ45 periode Januari 2015 - Desember 2020. Manfaat penelitian ini diharapkan dapat memberi informasi mengenai manajemen investasi sebagai bahan pertimbangan calon investor dalam memilih saham saham yang terdapat pada indeks LQ45 dengan salah satu upaya yaitu membentuk portofolio optimal dalam membuat keputusan investasi di masa yang akan datang, khususnya di masa pandemi pasca vaksinasi seperti saat ini.

\section{RUANG LINGKUP}

Dalam penelitian ini permasalahan mencakup:

1. Saham perbankan dalam indeks LQ45 periode Januari 2016 hingga Desember 2020;

2. Sektor saham perbankan BBCA, BBRI, BTPS, BBNI, BBTN, dan BMRI; dan

3. Mendapatkan nilai return dan risk dari saham yang dipilih.

Diversifikasi saham perlu dilakukan untuk mengamankan investasi saham seorang investor. Dengan melakukan diversifikasi saham, investor dapat meminimalkan risiko yang ada. Kemudian untuk tetap memaksimalkan gain yang ada, investor perlu menentukan komposisi atau proporsi saham yang optimal dalam portofolio mereka.

Hasil penelitian ini akan membantu para investor dalam pembentukan portofolio optimal khususnya yang tertarik untuk berinvestasi pada saham saham perbankan. Dan untuk para dosen, mahasiswa ataupun peneliti masa depan yang juga ingin meneliti tentang pembentukan portofolio optimal, maka penelitian ini dapat digunakan sebagai referensi dalam menyusun penelitian yang lebih baru.

\section{BAHAN DAN METODE}

Penelitian ini menggunakan metode pendekatan deskriptif dengan objek penelitian adalah portofolio saham dari emiten perbankan yang dapat memenuhi kriteria untuk diterima dalam model indeks tunggal.
Bahan/materi yang digunakan pada penelitian ini adalah saham - saham perusahan (emiten) perbankan yang terdaftar dalam indeks LQ45 pada periode Januari 2015 Desember 2020 yakni sebanyak 6 perusahaan seperti yang ditunjukkan pada tabel 1 .

Tabel 1. Nama Saham dan Nama Perusahaan

\begin{tabular}{|c|c|c|}
\hline No. & Nama Saham & Perusahaan \\
\hline 1 & BBCA & Bank Central Asia \\
\hline 2 & BBNI & Bank Negara Indonesia \\
\hline 3 & BBRI & Bank Rakyat Indonesia \\
\hline 4 & BBTN & Bank Tabungan Negara \\
\hline 5 & BMRI & Bank Mandiri \\
\hline 6 & BTPS & Bank BTPN Syariah \\
\hline
\end{tabular}

Return Portofolio adalah variabel yang digunakan pada penelitian ini, yaitu keuntungan yang diperoleh investor jika berinvestasi pada instrumen keuangan dalam satu periode tertentu, instrumen keuangan yang dimaksud adalah saham - saham emiten perbankan yang terdapat pada Indeks LQ45 periode Januari 2015 - Desember 2020. Risiko yang diperoleh dari gabungan antara saham atau kelompok instrumen keuangan dalam suatu portofolio disebut dengan Risiko Portofolio, yang dapat diukur dengan menggunakan standar deviasi dan Beta saham. Standar deviasi adalah gambaran dari gejolak Return saham dari Return ratarata. Adapun Beta merupakan koefisien yang digunakan dalam pengukuran pengaruh Return pasar terhadap perubahan Return saham dari suatu portofolio.

Data yang digunakan dalam penelitian ini adalah data sekunder, yaitu harga saham perusahaan yang terdaftar pada indeks LQ45, Indeks Harga Saham Gabungan (IHSG), dan suku bunga SBI periode Januari 2015 - Desember 2020. Data sekunder diperoleh dalam bentuk yang telah tersedia, telah dikumpulkan, dan telah diolah oleh pihak lain. Data sekunder tersebut diperoleh melalui website Bank Indonesia (BI), IDX, dan Yahoo Finance.

\subsection{Return Saham}

Return saham adalah tingkat keuntungan yang diperoleh investor atas suatu investasi yang dilakukan. Bentuk persamaan untuk memperoleh Return saham dalam penelitian ini dinyatakan pada (1).

$R_{i}=\frac{\left(P_{t}-P_{t-1}\right)}{P_{t-1}}(1)$

Keterangan (1):

$\mathrm{R}_{\mathrm{i}} \quad=$ Return dari saham $\mathrm{i}$

$\mathrm{P}_{\mathrm{t}} \quad=$ Harga pada periode sekarang 
$\mathrm{P}_{\mathrm{t}-1} \quad=$ Harga pada periode sebelumnya

Hasil perhitungan $R_{i}$ dianalisis menggunakan analisis deskriptif kuantitatif untuk menentukan tingkat keuntungan masing - masing saham seperti yang ditunjukkan pada tabel 2 .

Tabel 2. Nama Saham dan Nilai $R \mathbf{i}$

\begin{tabular}{|c|c|c|}
\hline No. & Nama Saham & $R \mathrm{i}$ \\
\hline 1 & BBCA & 1,5451 \\
\hline 2 & BBNI & 0,2375 \\
\hline 3 & BBRI & 0,8249 \\
\hline 4 & BBTN & 0,3320 \\
\hline 5 & BMRI & 0,3675 \\
\hline 6 & BTPS & 1,0891 \\
\hline
\end{tabular}

\subsection{Return Pasar}

Return Pasar adalah perolehan tingkat pengembalian dari investasi yang dilakukan pada seluruh saham yang terdapat di bursa, dimana seluruh saham tersebut dilihat dari Indeks Harga Saham Gabungan (IHSG) dihitung menggunakan rumus (Darmawan and Purnawati, 2015). Bentuk persamaan untuk menghitung Return pasar dalam penelitian ini dinyatakan pada (2).

$R_{m}=\frac{\left(l_{t}-l_{t-1}\right)}{l_{t-1}}(2)$

Keterangan (2):

$\mathrm{R}_{\mathrm{m}} \quad=$ Return pasar

$\mathrm{I}_{\mathrm{t}} \quad=$ Indeks pasar dari periode pengamatan

$\mathrm{I}_{\mathrm{t}-1} \quad=$ Indeks pasar pada periode sebelumnya

Hasil perhitungan $R_{m}$ dianalisis menggunakan analisis deskriptif kuantitatif untuk menentukan tingkat pengembalian pasar yang dihitung menggunakan IHSG seperti ditunjukkan pada tabel 3 .

Tabel 3. Nama Saham, Nilai $R \mathbf{i}, R \mathbf{m}$

\begin{tabular}{|c|c|c|c|}
\hline No. & Nama Saham & $R \mathrm{i}$ & $R \mathrm{~m}$ \\
\hline 1 & BBCA & 1,5451 & \multirow{2}{*}{0,3018} \\
\hline 2 & BBNI & 0,2375 & \\
\hline 3 & BBRI & 0,8249 & \\
\hline 4 & BBTN & 0,3320 & \\
\hline 5 & BMRI & 0,3675 & \\
\hline 6 & BTPS & 1,0891 & \\
\hline
\end{tabular}

\subsection{Expected Return Saham}

Expected Return Saham adalah Return yang diharapkan investor untuk didapatkan dari investasi yang dilakukan, dihitung menggunakan rumus yang dikemukakan (Zubir, 2011) dalam buku Manajemen Portofolio. Bentuk persamaan untuk menghitung Expected Return saham dalam penelitian ini dinyatakan pada (3).

$\mathrm{E}\left(R_{i}\right)=\frac{\sum_{t=1}^{n} R_{i t}}{n}(3)$

Keterangan (3):

$\mathrm{E}\left(R_{i}\right) \quad=$ Expected Return saham $\mathrm{i}$

$R_{i t} \quad=$ Return saham $\mathrm{i}$

$\mathrm{n} \quad=$ Jumlah observasi

Hasil perhitungan $E\left(R_{i}\right)$ dianalisis menggunakan analisis deskriptif kuantitatif untuk menentukan nilai keuntungan yang diharapkan investor dari masing - masing saham seperti ditunjukkan pada tabel 4.

Tabel 4. Nama Saham, Nilai $R \mathbf{i}, \boldsymbol{R m}$, dan $\mathrm{E}\left(\boldsymbol{R}_{\boldsymbol{i}}\right)$

\begin{tabular}{|c|c|c|c|c|}
\hline No. & Nama Saham & $R \mathrm{i}$ & $R \mathrm{~m}$ & $\mathrm{E}\left(R_{i}\right)$ \\
\hline 1 & BBCA & 1,5451 & \multirow{2}{*}{0,3018} & 0,3090 \\
\cline { 1 - 3 } & BBNI & 0,2375 & & 0,0475 \\
\hline 3 & BBRI & 0,8249 & & 0,1650 \\
\hline 4 & BBTN & 0,3320 & & 0,0664 \\
\hline 5 & BMRI & 0,3675 & & 0,0735 \\
\hline 6 & BTPS & 1,0891 & & 0,3630 \\
\hline
\end{tabular}

\subsection{Expected Return Pasar}

Expected Return Pasar merupakan Return yang diharapkan investor dapat dihasilkan oleh pasar dan dihitung dengan rumus yang dikemukakan oleh (Hartono, 2013). Bentuk persamaan untuk menghitung Expected Return pasar dalam penelitian ini dinyatakan pada (4).

$\mathrm{E}\left(R_{m}\right)=\frac{\sum_{t=1}^{n} \quad R_{m t}}{n}(4)$

Keterangan (4):

$\mathrm{E}\left(R_{m}\right)=$ Expected Return Pasar

$R_{m t} \quad=$ Return pasar pada periode $\mathrm{t}$

$\mathrm{n} \quad=$ Jumlah observasi

Hasil perhitungan $E\left(R_{m}\right)$ dianalisis menggunakan analisis deskriptif kuantitatif untuk menentukan nilai keuntungan yang diharapkan dari pasar berdasarkan IHSG seperti ditunjukkan pada tabel 5. 
Tabel 5. Nama Saham, Nilai $R \mathbf{i}, R \mathrm{~m}, \mathbf{E}\left(R_{i}\right) \operatorname{dan} \mathbf{E}(R \mathrm{~m})$

\begin{tabular}{|c|c|c|c|c|c|}
\hline No. & Nama Saham & $R \mathrm{i}$ & $R \mathrm{~m}$ & $\mathrm{E}\left(R_{i}\right)$ & $\mathrm{E}(R \mathrm{~m})$ \\
\hline 1 & BBCA & 1,5451 & \multirow[t]{6}{*}{0,3018} & 0,3090 & \multirow[t]{6}{*}{0,0603} \\
\hline 2 & BBNI & 0,2375 & & 0,0475 & \\
\hline 3 & BBRI & 0,8249 & & 0,1650 & \\
\hline 4 & BBTN & 0,3320 & & 0,0664 & \\
\hline 5 & BMRI & 0,3675 & & 0,0735 & \\
\hline 6 & BTPS & 1,0891 & & 0,3630 & \\
\hline
\end{tabular}

\subsection{Risiko Pasar}

Risiko pasar merupakan selisih dari Expected Return pasar dengan Return pasar dapat diperoleh menggunakan rumus (Hartono, 2014). Bentuk persamaan untuk menghitung risiko pasar dalam penelitian ini dinyatakan pada (5).

$\sigma_{m^{2}}=\sum_{t=1}^{n} \quad \frac{\left[R_{m t}-E\left(R_{m}\right)\right]^{2}}{n-1}(5)$

Keterangan (5):

$\sigma_{m^{2}} \quad=$ Variance Return pasar

$R_{m t} \quad=$ Return pasar pada periode $\mathrm{t}$

$E\left(R_{m}\right)=$ Expected Return pasar

$\mathrm{n} \quad=$ Jumlah observasi

\subsection{Beta}

Beta adalah koefisien untuk mengukur pengaruh dari Return pasar terhadap perubahan Return saham yang terjadi. Beta dihitung terlebih dahulu dengan menghitung kovarians dari Return pasar dan Return saham dengan menggunakan rumus (Darmawan and Purnawati, 2015). Bentuk persamaan untuk menghitung Beta dalam penelitian ini dinyatakan pada (6).

$\beta=\frac{N \Sigma X Y-(\Sigma X)(\Sigma Y)}{N \Sigma X^{2}-(\Sigma X)^{2}}(6)$

Keterangan (6):

$\mathrm{X}=$ Return pasar $(\mathrm{Rm})$

$\mathrm{Y}=$ Return saham $(\mathrm{Ri})$

$\mathrm{N}=$ Jumlah data

$\beta=$ Beta saham

Atau dapat dinyatakan pada (7).

$\beta_{i}=\frac{\operatorname{Cov}\left(R_{i} R_{m}\right)}{\operatorname{Var}\left(R_{m}\right)}(7)$

Keterangan (7):

$\beta_{i}=$ Beta saham

$\mathrm{C}_{\mathrm{ov}}=$ Covarian

$\mathrm{V}_{\mathrm{ar}}=$ Varians

$R_{i}=$ Return saham

$R_{m}=$ Return Pasar
Selanjutnya Beta dapat dihitung, seperti dinyatakan pada (8).

$\beta_{i}=\frac{\sigma_{i m}}{\sigma_{m^{2}}}(8)$

Keterangan (8):

$\beta_{i} \quad=$ Beta saham $\mathrm{i}$

$\sigma_{i m}=$ Kovarian antara Return saham i dan Return pasar

$\sigma_{m^{2}} \quad=$ Variance Return pasar

Untuk nilai Beta $\left(\beta_{i}\right)$ diolah seperti yang ditunjukkan pada tabel 6 .

Tabel 6. Nilai $\beta \mathbf{i}$

\begin{tabular}{|c|c|c|}
\hline No. & Nama Saham & $\beta \mathrm{i}$ \\
\hline 1 & BBCA & 20,481 \\
\hline 2 & BBNI & 3,148 \\
\hline 3 & BBRI & 10,936 \\
\hline 4 & BBTN & 4,401 \\
\hline 5 & BMRI & 4,872 \\
\hline 6 & BTPS & 12,031 \\
\hline
\end{tabular}

\subsection{Alpha}

Alpha adalah variabel yang tidak dipengaruhi oleh Return pasar, dihitung dengan persamaan sebagaimana yang dinyatakan pada (9).

$\alpha_{i}=E\left(R_{i}\right)-\beta_{i} . E\left(R_{m}\right)(9)$

Keterangan (9):

$\alpha_{i} \quad=$ Alpha saham i

$E\left(R_{i}\right)=$ Expected Return saham $\mathrm{i}$

$E\left(R_{m}\right)=$ Expected Return pasar

Untuk nilai Alpha $\left(\alpha_{i}\right)$ diolah seperti yang ditunjukkan pada tabel 7 .

Tabel 7. Nilai $\beta i$ dan $\alpha i$

\begin{tabular}{|c|c|c|c|}
\hline No. & Nama Saham & $\beta \mathrm{i}$ & $\alpha \mathrm{i}$ \\
\hline 1 & BBCA & 20,481 & $-0,927$ \\
\hline 2 & BBNI & 3,148 & $-0,142$ \\
\hline 3 & BBRI & 10,936 & $-0,495$ \\
\hline 4 & BBTN & 4,401 & $-0,199$ \\
\hline 5 & BMRI & 4,872 & $-0,221$ \\
\hline 6 & BTPS & 12,031 & $-0,363$ \\
\hline
\end{tabular}




\subsection{Excess Return to Beta}

Excess Return to Beta merupakan pengukuran kelebihan Return relatif terhadap satu unit risiko yang tidak dapat didiversifikasikan yang diukur dengan Beta (Darmawan and Purnawati, 2015). Bentuk persamaan untuk menghitung Excess Return to Beta dalam penelitian ini dinyatakan pada (10).

$E R \beta_{i}=\frac{E\left(R_{i}\right)-R_{b r}}{\beta_{i}}(10)$

Keterangan (10):

$E R \beta_{i}=$ Excess Return to Beta

$E\left(R_{i}\right) \quad=$ Expected Return saham $\mathrm{i}$

$R_{b r} \quad=$ Return aktiva bebas risiko

$\beta_{i}=$ Beta saham i

Untuk nilai Excess Return to Beta $\left(E R \beta_{i}\right)$ diolah seperti ditunjukkan pada tabel 8.

Tabel 8. Nilai $\beta i$, $\alpha$, dan $\mathrm{E}(\mathrm{RBi})$

\begin{tabular}{|c|c|c|c|c|}
\hline No. & $\begin{array}{c}\text { Nama } \\
\text { Saham }\end{array}$ & $\beta \mathrm{i}$ & $\alpha \mathrm{i}$ & $\mathrm{E}(\mathrm{RBi})$ \\
\hline 1 & BBCA & 20,481 & $-0,927$ & 0,043 \\
\hline 2 & BBNI & 3,148 & $-0,142$ & $-6,469$ \\
\hline 3 & BBRI & 10,936 & $-0,495$ & 0,004 \\
\hline 4 & BBTN & 4,401 & $-0,199$ & $-9,156$ \\
\hline 5 & BMRI & 4,872 & $-0,221$ & $-7,543$ \\
\hline 6 & BTPS & 12,031 & $-0,363$ & 0,017 \\
\hline
\end{tabular}

\section{PEMBAHASAN}

Peneliti memutuskan untuk menguji teori yang dikemukakan melakukan diversifikasi saham sebagai instrumen investasi yang dipilih karena investasi saham menjanjikan Return yang tinggi jika dilakukan dalam kurun waktu yang cukup lama. Tentunya risiko yang dihadapi juga besar, oleh karenanya peneliti memilih saham dari perusahaan perusahaan perbankan yang termasuk dalam indeks LQ45 dikarenakan nilai kapitalisasi pasarnya yang tinggi dan tentunya menjamin kinerja portofolio tetap stabil. Adapun saham - saham yang dipilih adalah BBNI, BBCA, BBRI, BBTN, BMRI dan BTPS.

Peneliti menggunakan model indeks tunggal dalam menyusun proporsi dana yang akan diinvestasikan. Langkah - langkah yang diambil dalam pembentukan portofolio optimal dengan menggunakan Model Indeks Tunggal berdasarkan data yang dikumpulkan adalah:

\subsection{Menghitung Return dari Masing-Masing Saham Serta Pasar}

Return saham merupakan tingkat pengembalian yang diperoleh melalui sejumlah investasi saham, Return saham dihitung menggunakan rumus sebagaimana yang dinyatakan pada (11).

$R_{i}=\frac{\left(P_{t}-P_{t-1}\right)}{P_{t-1}}(11)$

Keterangan (11):

$\mathrm{R}_{\mathrm{i}} \quad=$ Return dari saham $\mathrm{i}$

$\mathrm{P}_{\mathrm{t}} \quad=$ Harga pada periode sekarang

$\mathrm{P}_{\mathrm{t}-1} \quad=$ Harga pada periode sebelumnya

Return pasar adalah tingkat pengembalian atau penghasilan yang diperoleh investor melalui investasi pada saham yang terdapat di bursa, dimana pada penelitian ini Return pasar tercermin pada Return Indeks LQ45, Return pasar dapat diperoleh menggunakan rumus sebagaimana yang dinyatakan pada (12).

$R_{m}=\frac{\left(l_{t}-l_{t-1}\right)}{l_{t-1}}(12)$

Keterangan (12):

$\mathrm{R}_{\mathrm{m}} \quad=$ Return pasar

$\mathrm{I}_{\mathrm{t}} \quad=$ Indeks pasar dari periode pengamatan

$\mathrm{I}_{\mathrm{t}-1} \quad=$ Indeks pasar pada periode sebelumnya

\subsection{Menghitung Expected Return dari Masing-Masing Saham serta Pasar}

Expected Return adalah Return yang diharapkan oleh investor akan dapat dihasilkan dari investasi yang dilakukan, dihitung dengan rumus sebagaimana yang dinyatakan pada (13).

$\mathrm{E}\left(R_{i}\right)=\frac{\sum_{t=1}^{n} \quad R_{i t}}{n}(13)$

Keterangan (13):

$\mathrm{E}\left(R_{i}\right) \quad=$ Expected Return saham $\mathrm{i}$

$R_{i t} \quad=$ Return saham i

$\mathrm{n} \quad=$ Jumlah observasi

Expected Return pasar merupakan Return yang diharapkan investor dapat dihasilkan oleh pasar dan dihitung dengan persamaan sebagaimana yang dinyatakan pada (14).

$\mathrm{E}\left(R_{m}\right)=\frac{\sum_{t=1}^{n} \quad R_{m t}}{n}(14)$

Keterangan (14):

$\mathrm{E}\left(R_{m}\right)=$ Expected Return Pasar

$R_{m t} \quad=$ Return pasar pada periode $\mathrm{t}$

$\mathrm{n} \quad=$ Jumlah observasi

Data yang digunakan dalam perhitungan tingkat keuntungan pasar adalah berdasarkan nilai Indeks Harga Saham Gabungan (IHSG) pada periode tahun 2016 2020, sehingga diperoleh nilai keuntungan pasar (Rm) adalah sebesar 0,3018 dan rata-rata keuntungan pasar $(\mathrm{E}(\mathrm{Rm}))$ adalah sebesar 0,0603.

Dari hasil perhitungan yang ditunjukkan pada Tabel 4, diketahui bahwa nilai keuntungan tiap - tiap saham berbeda. Tabel 4 menunjukkan bahwa nilai E(Ri) 
atau keuntungan yang diharapkan semua sampel perusahaan bernilai positif, hal tersebut berarti 6 emiten saham perbankan yang menjadi sampel penelitian ini dapat memberikan keuntungan. Nilai E(Ri) memiliki nilai ekspektasi yang dihitung dari data historis pergerakan harga saham.

\subsection{Menghitung Risiko Pasar}

Risiko pasar merupakan selisih antara Expected Return pasar dengan Return pasar yang dapat diperoleh dengan persamaan sebagaimana yang dinyatakan pada (15).

$$
\sigma_{m^{2}}=\sum_{t=1}^{n} \quad \frac{\left[R_{m t}-E\left(R_{m}\right)\right]^{2}}{n-1}(15)
$$

Keterangan (15):

$$
\begin{array}{ll}
\sigma_{m^{2}} & =\text { Variance Return pasar } \\
R_{m t} & =\text { Return } \text { pasar pada peiode } \mathrm{t} \\
E\left(R_{m}\right) & =\text { Expected Return pasar } \\
\mathrm{n} & =\text { Jumlah observasi }
\end{array}
$$

\subsection{Menghitung Beta dan Alpha Tiap - Tiap Saham}

Koefisien pengukur pengaruh Return pasar terhadap perubahan yang terjadi pada Return saham adalah Beta. Untuk memperoleh Beta, kovarians antara Return pasar dan Return saham dapat dihitung terlebih dahulu dengan menggunakan persamaan sebagaimana yang dinyatakan pada (16)

$$
\sigma_{i m}=\sum_{i=1}^{m} \quad\left[R_{i}-E\left(R_{i}\right)\right]\left[R_{m}-E\left(R_{m}\right)\right](16)
$$

Keterangan (16):

$\sigma_{i m}=$ Kovarian antara Return saham i dan Return pasar

$R_{i} \quad=$ Return saham $\mathrm{i}$

$E\left(R_{i}\right) \quad=$ Expected Return saham $\mathrm{i}$

$R_{m} \quad=$ Return pasar

$E\left(R_{m}\right)=$ Expected Return pasar

Selanjutnya, Beta diperoleh menggunakan persamaan sebagaimana yang dinyatakan pada (17):

$\beta_{i}=\frac{\sigma_{i m}}{\sigma_{m^{2}}}(17)$

Keterangan (17):

$\beta_{i}=$ Beta saham i

$\sigma_{i m}=$ Kovarian antara Return saham i dan Return pasar

$\sigma_{m^{2}} \quad=$ Variance Return pasar

Alpha adalah variabel yang tidak terpengaruh oleh Return pasar dan diperoleh dengan persamaan sebagaimana yang dinyatakan pada (18).

$\alpha_{i}=E\left(R_{i}\right)-\beta_{i} . E\left(R_{m}\right)$
Keterangan (18):

$\alpha_{i} \quad=$ Alpha saham i

$E\left(R_{i}\right)=$ Expected Return saham i

$E\left(R_{m}\right)=$ Expected Return pasar

Menentukan nilai Return aktiva bebas risiko (RBR) diwakili oleh tingkat suku bunga SBI bulanan selama dalam periode penelitian yaitu pada Januari 2021 - Maret 2021 adalah sebesar 3,75\% (0,0375). SBI dianggap sebagai aktiva bebas risiko sebab dikeluarkan oleh Bank Sentral (Bank Indonesia) dan merupakan salah satu instrumen investasi dengan jangka waktu pendek. Jika $\mathrm{E}(\mathrm{Ri})>\mathrm{RBR}$ dari sebuah saham, maka saham tersebut terpilih untuk dianalisis kemudian, sebaliknya jika E(Ri) < RBR, maka saham tersebut diabaikan karena memiliki nilai Expected Return saham dibawah nilai Return aktiva bebas risiko dan tidak disertakan dalam proses analisis selanjutnya.

Excess Return to Beta berarti mengukur kelebihan Return relatif terhadap satu unit risiko yang tidak dapat diversifikasi yang diukur dengan Beta. Tingkat Excess Return to Beta (ERBi) diperoleh dengan persamaan sebagaimana yang dinyatakan pada (19).

$E R \beta_{i}=\frac{E\left(R_{i}\right)-R_{b r}}{\beta_{i}}(19)$

Keterangan (19):

$E R \beta_{i}=$ Excess Return to Beta

$E\left(R_{i}\right)=$ Expected Return saham $\mathrm{i}$

$R_{b r} \quad=$ Return aktiva bebas risiko

$\beta_{i} \quad=$ Beta saham $\mathrm{i}$

Cut off rate $(\mathrm{Ci})$ merupakan titik pembatas yang digunakan untuk menentukan sebuah saham dapat dimasukan atau tidak ke dalam portofolio. Saham yang dipilih adalah dengan nilai $\mathrm{Ci} \leq$ ERB. Sebelum memperoleh nilai $\mathrm{Ci}$, dihitung terlebih dahulu $\mathrm{Ai}$ dan $\mathrm{Bi}$ dengan persamaan sebagaimana yang dinyatakan pada (20) dan (21)

$A_{i}=\frac{\left[E\left(R_{i}\right)-R_{b r}\right] \beta_{i}}{\sigma_{e i^{2}}}(20)$

Keterangan (20):

$E\left(R_{i}\right) \quad=$ Expected Return saham $\mathrm{i}$

$R_{b r} \quad=$ Return aktiva bebas risiko

$\beta_{i} \quad=$ Beta saham i

$\sigma_{e i^{2}}=$ Variance dari kesalahan residu

$B_{i}=\frac{\beta_{i^{2}}}{\sigma_{e i^{2}}}(21)$

Keterangan (21):

$B_{i} \quad=$ Beta saham $\mathrm{i}$

$\sigma_{e i^{2}}=$ Variance dari kesalahan residu 
Setelah diperoleh nilai Ai dan Bi, selanjutnya $\mathrm{Ci}$ dapat dihitung dengan persamaan sebagaimana yang dinyatakan pada (22).

$C_{i}=\frac{\sigma_{m^{2}} \sum_{j=1}^{i} \quad A_{j}}{1+\sigma_{m^{2}} \sum_{j=1}^{i} \quad B_{j}}(22)$

Keterangan (22):

$\sigma_{M^{2}} \quad=$ Variance dari Return indeks pasar

Untuk hasil perhitungan nilai (Ai), (Bi) dan (Ci) yang telah diolah ditunjukkan pada tabel 9.

Tabel 9. Nilai Ai, Bi, dan Ci

\begin{tabular}{|c|c|c|c|c|}
\hline No. & Nama Saham & $\mathrm{Ai}$ & $\mathrm{Bi}$ & $\mathrm{Ci}$ \\
\hline 1 & BBCA & $-0,514$ & 5,259 & $-0,007$ \\
\hline 2 & BBNI & $-0,906$ & 581,069 & 0,001 \\
\hline 3 & BBRI & $-0,366$ & 20,896 & $-0,004$ \\
\hline 4 & BBTN & 0,267 & 203,951 & 0,001 \\
\hline 5 & BMRI & 0,143 & 153,394 & 0,001 \\
\hline 6 & BTPS & $-1,141$ & 16,837 & $-0,013$ \\
\hline
\end{tabular}

Berdasarkan tabel 8 seluruh saham memiliki nilai $\operatorname{Beta}(\beta)>1$ dan saham perusahaan Bank Central Asia (BBCA) merupakan yang tertinggi yakni sebesar 20,481. Hal ini menunjukkan saham tersebut sangat terpengaruh oleh perubahan kondisi pasar. Artinya setiap terdapat perubahan sebesar $1 \%$, maka hal tersebut akan mengakibatkan perubahan keuntungan dari sekuritas tersebut searah yang sama sebesar $20,481 \%$.

Berdasarkan Tabel 8 terlihat bahwa hanya terdapat empat saham yang memiliki nilai Excess Return to Beta (ERB) besar dan positif yaitu Bank Central Asia (BBCA) sebesar 0,043, Bank Rakyat Indonesia (BBRI) sebesar 0,004 dan Bank BTPN Syariah (BTPS) sebesar 0,017 . Portofolio optimal akan berisi dengan aktiva yang memiliki nilai rasio ERB tinggi. Sedangkan nilai rasio ERB rendah tidak masuk dalam kategori portofolio optimal.

Dalam menentukan cut off point $\left(\mathrm{C}^{*}\right)$, perlu didapatkan nilai Ci dari masing - masing saham. Besaran cut off point mengacu kepada nilai $\mathrm{Ci}$ yang terbesar. Penentuan kandidat portofolio optimal adalah dengan kriteria jika ERB saham $\geq C^{*}$. Nilai Cut off point dari hasil perhitungan yang diperoleh adalah senilai 0,0013 .

\subsection{Menentukan saham - saham yang masuk} portofolio optimal

Dari hasil perhitungan pada tabel 9 dapat diketahui nilai cut-off point adalah sebesar 0.0013 dan merupakan batas penentuan saham - saham yang akan masuk ke dalam portofolio optimal. Saham yang masuk ke dalam portofolio optimal adalah saham - saham yang memiliki nilai ERB lebih besar atau sama dengan cut-off point. Ditunjukkan pada tabel 8 dan 9, tiga saham terpilih karena memiliki nilai ERB diatas nilai cut-off point. Saham yang terpilih ke dalam daftar portofolio optimal pada penelitian ini adalah BBCA, BBRI dan BTPS.

\subsection{Menghitung proporsi masing-masing saham}

Menghitung besaran proporsi dana dilakukan setelah portofolio optimal terbentuk, diperoleh dengan persamaan sebagaimana yang dinyatakan pada (23) dan (24).

$W_{i}=\frac{Z_{i}}{\sum_{j=1}^{k} Z_{j}}(23)$

Dengan $Z_{i}$ sebesar: $Z_{i}=\frac{\beta_{i}}{\sigma_{e i^{2}}}\left(E R B_{i}-C^{*}\right)$

Keterangan (23) dan (24):

$W_{i} \quad=$ Proporsi saham ke $\mathrm{i}$

$k=$ Jumlah saham di portofolio

$B_{i} \quad=$ Beta saham i

$\sigma_{e i^{2}} \quad=$ Variance dari kesalahan residu

$E R \beta_{i}=$ Excess Return to Beta saham $\mathrm{i}$

$\mathrm{C}^{*}=$ Cut off Point yang merupakan nilai $\mathrm{Ci}$ terbesar

Dengan menghitung nilai $\mathrm{Zi}$, Wi dan $\% \mathrm{Wi}$ peneliti dapat mengetahui saham - saham pembentuk portofolio optimal seperti yang ditunjukkan pada tabel 10.

Tabel 10. Nilai Zi, Wi, dan \%Wi

\begin{tabular}{|c|c|c|c|c|}
\hline No. & Nama Saham & $\mathrm{Zi}$ & Wi & $\% \mathrm{Wi}$ \\
\hline 1 & BBCA & $-0,094$ & 0,564 & $56 \%$ \\
\hline 2 & BBRI & $-0,011$ & 0,067 & $7 \%$ \\
\hline 3 & BTPS & $-0,062$ & 0,370 & $37 \%$ \\
\hline \multicolumn{2}{|c|}{ TOTAL } & $-0,168$ & & $100 \%$ \\
\hline
\end{tabular}

Setelah diperoleh saham - saham perusahaan yang masuk dalam daftar portofolio optimal, peneliti menentukan proporsi dana investasi berdasarkan preferensi calon investor, yaitu dengan melihat saham yang menawarkan tingkat keuntungan tertinggi dengan risiko terendah dan diperoleh proporsi sebagai berikut: BBCA 56\%, BBRI 7\% dan BTPS 37\%.

\section{KESIMPULAN}

Dengan keadaan yang mulai membaik sejak terjadi pandemic Covid-19, kemampuan masyarakat dalam sektor ekonomi pun mulai membaik, peluang ini lah yang diambil oleh investor untuk kembali memulai investasi. Berdasarkan penelitian yang telah dilakukan, diperoleh hasil bahwa saham - saham pada sector perbankan pada indeks LQ45 yang memiliki potensi optimal untuk mendapatkan Return tertinggi dengan risk 
terendah dengan menggunakan model indeks tunggal pada periode 2016 - 2020 memiliki proporsi sebagai berikut: BBCA (Bank Central Asia) sebesar 56\%, Bank Rakyat Indonesia (BBRI) sebesar 7\%, dan Bank BTPN Syariah (BTPS) sebesar 37\%.

Perbankan merupakan perusahaan penopang perekonomian suatu bangsa, tidak terkecuali di Indonesia. Di Indonesia sendiri, saham - saham perbankan selalu masuk dalam daftar saham - saham pembentuk harga IHSG. Tidak sedikit saham - saham perbankan menjadi saham blue chip yang sangat diminati para investor. Dari kondisi keuangan perbankan dapat dilihat apakah fungsi perbankan sebagai mediator berjalan dengan baik atau tidak. Oleh karenanya berinvestasi pada sektor perbankan dapat dijadikan sebagai salah satu portofolio yang wajib dimiliki.

Penelitian ini menambah variasi tentang pembentukan portofolio optimal dengan sampel saham perbankan dimana pada penelitian - penelitian sebelumnya berfokus pada saham - saham manufaktur dan saham - saham yang lebih umum tidak terbatas pada saham perbankan.

\section{SARAN}

Calon investor yang akan memulai investasi pada sektor saham perbankan di pasar modal dapat menerapkan portofolio optimal dengan metode indeks tunggal yang tergabung dalam daftar indeks LQ45 dari hasil penelitian ini, adalah dengan periode 2016 - 2020.

Pola pembentukan portofolio optimal dengan metode indeks tunggal yang tergabung dengan tidak terbatas dalam indeks LQ45 dan sektor perbankan berdasarkan rekam jejak setiap emiten, juga dapat diterapkan oleh calon investor guna memperoleh hasil investasi yang optimal.

\section{DAFTAR PUSTAKA}

Dahlan, S., Topowijono and Z.A, Z. (2013) 'Penggunaan Single Index Model Dalam Analisis Portofolio Untuk Meminimumkan Risiko Bagi Investor Di Pasar Modal (Studi Pada Saham Perusahaan Yang Tercatat Dalam Indeks LQ 45 Di Bursa Efek Indonesia Periode 2010-2012)', Jurnal Administrasi Bisnis (JAB), 6(2), pp. 1-10.

Darmawan, I. and Purnawati, N. (2015) 'Pembentukan Portofolio Optimal Pada Saham-Saham Di Indeks Lq 45 Dengan Menggunakan Model Indeks Tunggal', E-Jurnal Manajemen Universitas Udayana, 4(12), p. 251939.

Firdaus, Iwan. Anah, Sri. Nadira, F. (2018) 'Analisis Pembentukan Portofolio Optimal Menggunakan Model Indeks Tunggal', Jurnal Ekonomi, 23(2), pp. 203-226.

Firdausy, A. D. (2015) 'ANALISIS INVESTASI MELALUI PENETAPAN PORTOFOLIO SAHAM OPTIMAL PADA SAHAM LQ-45 BURSA EFEK INDONESIA', Unej.
Hadiwardoyo, W. (2020) 'Kerugian Ekonomi Nasional Akibat Pandemi Covid-19', Baskara: Journal of Business and Entrepreneurship, 2(2), pp. 83-92. doi: 10.24853/baskara.2.2.83-92.

Hartono, J. (2013) Teori Portofolio dan Analisis Investasi. Edisi Kede. Yogyakarta: BPFE.

Hartono, J. (2014) Teori Portofolio dan Analisis Investasi. Edisi Kese. Yogyakarta: BPFE.

Kewal, S. S. (2013) 'Pembentukan Portofolio Optimal Saham-Saham Pada Periode Bullish Di Bursa Efek Indonesia', Jurnal Economia, 9(1), pp. 81-91. doi: 10.21831/economia.v9i1.1378.

Nalini, R. (2014) 'Optimal Portfolio Construction Using Sharpe's Single Index Model-A Study of Selected Stocks From BSE', International Journal of Advanced Research in Management and Social Sciences, 2(12), pp. 72-93. Available at: www.graph.co.uk.

Oktaviani, B. N. and Wijayanto, A. (2016) 'Aplikasi Single Index Model dalam Pembentukan Portofolio Optimal Saham LQ45 dan Jakarta Islamic Index', Management Analysis Journal, 5(3), pp. 189-202. doi: 10.15294/maj.v5i3.10651.

Pardosi, B. and Wijayanto, A. (2013) 'Analisis Perbedaan Return Dan Risiko Saham Portofolio Optimal Dengan Bukan Portofolio Optimal', Management Analysis Journal, 4(1). doi: 10.15294/maj.v4i1.7210.

Pratama, Y. H. and Budiyanto (2016) 'ANALISIS PORTOFOLIO OPTIMAL DENGAN MODEL INDEKS TUNGGAL PADA SEKTOR PERTAMBANGAN', 6, pp. 1-16.

Rarastiti, H., Handayani, S. R. and Sudjana, N. (2013) 'Pmbentukan Portofolio Optimal Dengan Menggunakan Single Index Model ( Studi Pada Perusahaan Food and Beverages yang Terdaftar di BEI', Jurnal Administrasi Bisnis (JAB), 6(1).

Wibowo, W. M., Rahayu, S. M. and Endang, M. G. (2014) 'Penerapan Model Indeks Tunggal Untuk Menetapkan Komposisi Portofolio Optimal (Studi Pada Saham-Saham LQ 45 yang Listing di Bursa Efek Indonesia (BEI) Tahun 2010-2012)', Jurnal Administrasi Bisnis S1 Universitas Brawijaya, 9(1), p. 80987.

Zubir, Z. (2011) Manajemen Portofolio: Penerapannya dalam Investasi Saham. Jakarta: Salemba Empat. 